DÍDAC JORDA-CAPDEVILA (Orcid ID : 0000-0002-5670-829X)

DR RACHEL STUBBINGTON (Orcid ID : 0000-0001-8475-5109)

DR THIBAULT DATRY (Orcid ID : 0000-0003-1390-6736)

Article type : Review

Handling Editor: Vitor Paiva

\title{
Accounting for flow intermittency in environmental flows design
}

Acuña V. ${ }^{1,2}$, Jorda-Capdevila D.. ${ }^{* 1,2}$, Vezza P. ${ }^{3}$, De Girolamo A.M. ${ }^{4}$, McClain M.E. ${ }^{5,6}$, Stubbington R. ${ }^{7}$, Pastor A.V. ${ }^{8}$, Lamouroux N. ${ }^{9}$, von Schiller D. ${ }^{10}$, Munné A. ${ }^{11}$, Datry T. ${ }^{10}$

1. Catalan Institute for Water Research (ICRA), Carrer Emili Grahit 101, 17003 Girona (Spain).

2. Universitat de Girona (UdG), Plaça de Sant Domènec 3, 17004 Girona (Spain).

3. Department of Environment, Land and Infrastructure Engineering (DIATI), Politecnico di Torino, C.so Duca degli Abruzzi 24, 10129 Torino (Italy).

4. Water Research Institute, National Research Council (IRSA, CNR), 70132 Bari (Italy).

5. IHE Delft Institute for Water Education. Department of Water Science and Engineering, Westvest 7, 2601DA Delft (The Netherlands).

6. Delft University of Technology, Faculty of Civil Engineering and Geosciences, Stevinweg 1, 2628 CN Delft (The Netherlands).

This article has been accepted for publication and undergone full peer review but has not been through the copyediting, typesetting, pagination and proofreading process, which may lead to differences between this version and the Version of Record. Please cite this article as doi: $\underline{10.1111 / 1365-2664.13590}$

This article is protected by copyright. All rights reserved 
7. School of Science and Technology, Nottingham Trent University, Nottingham NG11 8NS (United Kingdom).

8. Centre for Ecology, Evolution and Environmental Changes (CE3C), Climate Change Impacts, Adaptation and Modelling (CCIAM), Faculdade de Ciências da Universidade de Lisboa, Campo Grande, 1749-016 Lisbon (Portugal).

9. IRSTEA - Lyon, RiverLy Research Unit, 69626 Villeurbanne (France).

10. Professor Serra Húnter, Department of Evolutionary Biology, Ecology and Environmental Sciences, Faculty of Biology, University of Barcelona, Av. Diagonal 643, 08028 Barcelona (Spain).

11. Catalan Water Agency (ACA), Carrer Provença 204, 08036 Barcelona (Spain).

Author to whom correspondence should be addressed $\left(^{*}\right)$ : djorda@icra.cat.

Running head: flow intermittency and environmental flows.

Keywords: freshwater ecosystems, habitat modelling, temporary waterways, environmental policy, flow regime, ecological flows, socio-ecological systems, water management. 


\section{Abstract}

1. River ecosystems worldwide are affected by altered flow regimes, and an advanced science and practice of environmental flows has developed to understand and reduce these impacts. But most environmental flows approaches ignore flow intermittency, which is a natural feature of $30 \%$ of the global river network length. Ignoring flow intermittency when setting environmental flows in naturally intermittent rivers might lead to deleterious ecological effects.

2. We review evidence of the ecological effects of flow intermittency and provide guidance to incorporate intermittency (non-flow events) into existing methods judged as suitable for application in temporary waterways.

3. To better integrate non-flow events into hydrological methods, we propose a suite of new indicators to be used in the Range of Variability Approach. These indicators reflect dry periods and the unpredictable nature of temporary waterways. We develop a predictability index for protecting those species adapted to temporary conditions.

4. For hydraulic habitat models, we find that mesohabitat methods are particularly effective for describing complex habitat dynamics during dry phases. We present an example of the European eel to show the relationship between discharge and non-flow days and wet area, habitat suitability, and connectivity.

5. We find that existing holistic approaches may be applied to temporary waterways without significant structural alteration to their stepwise frameworks, but new component methods are needed to address flow-related aspects across both flow and non-flow periods of the flow regime.

6. Synthesis and applications. Setting environmental flow requirements for temporary waterways requires modification and enhancement of existing approaches and methodologies, most notably the explicit consideration of non-flow events and greater integration of specific geomorphic, hydrogeologic, and hydraulic elements. Temporary waterways are among the freshwater ecosystems most vulnerable to alterations in flow regimes, and they are also under great pressure. The methodological modifications recommended in this paper will aid water managers in protecting key components of temporary flow regimes, thereby preserving their unique ecology and associated services. 


\section{Introduction}

The natural flow regime of streams and rivers is commonly altered by anthropogenic activities, and will be further modified by the interacting effects of climate change and increasing human water demands (Schneider et al. 2013), especially in water scarce regions (Gerten et al. 2013; Kummu et al. 2016). Alterations to the flow regime are known to cause deleterious effects on freshwater ecosystem biodiversity, processes and services (Arthington et al. 2006; Poff et al. 2007).

Environmental flows (eflows) mitigate the deleterious effects of flow regime alterations (Arthington et al. 2010) and have been supported by national and international environmental policies, such as the European Water Framework Directive (Acreman \& Ferguson 2010; European Commission 2016). Environmental flows describe the quantity, timing, and quality of freshwater flows and levels necessary to sustain aquatic ecosystems which, in turn, support human cultures, economies, sustainable livelihoods, and well-being (Arthington et al. 2018), while also taking into account sediment transport to preserve river geomorphology downstream and deltas in river mouths (Wohl et al. 2015). Existing methods to design eflows can be broadly differentiated in those based on only natural flow regime components (Acreman et al. 2014), those that also consider habitat conditions (Stanalker et al. 1995; Lamouroux \& Jowett 2005), and those additionally considering socio-economic conditions (King \& Louw 1998; King, Brown \& Sabet 2003; Richter et al. 2006).

Around $30 \%$ of the global river network length is intermittent (Pekel et al. 2016; Schneider et al. 2017), and is also in need of eflows implementation. Intermittency is considered as an extreme flow event in the natural flow regime framework (Poff et al. 1997), and it is a key determinant of biodiversity and ecosystem function in temporary waterways (Acuña, Hunter \& Ruhí 2017; Leigh \& Datry 2017). However, flow intermittency has been rarely considered in the design of eflows, often due to scarce available data on natural flows (gauging stations are rarely located in temporary waterways) and the complexity of recognising how the effects of non-flow events on biological communities should be dealt with. Ignoring flow intermittency when setting eflows in these rivers might lead to deleterious ecological effects (Seaman et al. 2016a). 
Here, we (i) review existing evidence of the ecological effects of flow intermittency on temporary waterways and discuss the likely consequences of its alteration; (ii) review current methodological approaches to account for flow intermittency in the design of eflows for temporary waterways; and (iii) discuss their limitations and propose modifications to properly account for flow intermittency.

\section{i) Socio-ecological effects of flow intermittency}

Flow intermittency can be characterised by its spatial and temporal components; in space, the location and length of the non-flowing sections in the river network, and in time, the duration, frequency, timing and predictability of the non-flow events (Tonkin et al. 2017). Different combinations of these spatial and temporal components provide a high diversity of temporary waterways typologies (Eng, Wolock \& Dettinger 2016), to which some species are specifically adapted (Bogan, Boersma \& Lytle 2015). Beyond the spatial and temporal components, non-flowing sections might be mainly differentiated by the presence of permanent pools and by the severity of conditions in the river bed (temperature and humidity) (Bogan, Boersma \& Lytle 2015; Colls et al. 2019). The specific adaptations of species inhabiting temporary waterways mean that any significant change in, for example, the duration of non-flow events might alter biodiversity and thus ecosystem function (Datry 2012; Jaeger, Olden \& Pelland 2014; Garcia et al. 2017b). However, little research has explored the relationship between these spatial and temporal components. Only $4 \%$ of published studies in peer-reviewed journals on flow intermittency to date have analysed the effects of spatial or temporal components (Colls et al. 2019), restricting our ability to predict the ecological effects of changing flow intermittency patterns in temporary waterways.

Water resources management and climate change are the main drivers altering the spatial and temporal components of flow intermittency (Döll \& Zhang 2010). Management of water resources can even lead permanent watercourses to become temporary (artificial intermittency) or temporary to become permanent (artificial permanency) (Döll \& Schmied 2012; Acuña, Hunter \& Ruhí 2017). Land-use change also influences spatial and temporal variability in intermittency, for example the replacement of pasture by forest can cause shifts from permanent to intermittent flow (Gallart \& Llorens 2004). 
Observations over recent decades, as well as current global-scale climate change models, indicate changing precipitation and temperature patterns, with an overall increase in the temporal variability and a higher frequency of extreme events such as floods and supra-seasonal droughts (Döll \& Schmied 2012). These changes are leading to longer and more frequent non-flow events, to longer non-flowing river reaches (Pumo et al. 2016; De Girolamo et al. 2017b; Garcia et al. 2017a), and to fundamental shifts from permanent to temporary river flow regimes (Döll \& Schmied 2012).

Knowledge about the ecological consequences of flow intermittency alteration is fragmented (Datry, Larned \& Tockner 2014). For example, artificial permanency will affect biodiversity, as specialists including rare species may be replaced by competitive generalists (Gehrke \& Harris 2001); lentic and terrestrial species associated with pool and dry phases may be lost; and desiccation-sensitive non-native invasive species may also be favored (Múrria, Bonada \& Prat 2008; Poznańska et al. 2013). Although local (alpha) biodiversity may increase with increasing permanence, spatial and temporal regional (gamma) diversity are likely to decline due to reduced hydrological habitat diversity (Larned et al. 2010). In terms of ecosystem function, losing the characteristic alternation of wet and dry phases in temporary waterways will change their unique "biogeochemical heartbeat", with pulsed temporal and spatial variations in nutrient and organic matter inputs, instream processing, and downstream transport (Acuña et al. 2004; Jacobson \& Jacobson 2013; Shumilova et al. 2019).

We believe that although social perception of flow intermittency can be negative (Armstrong et al. 2012; Leigh et al. 2019), from an ecological perspective, artificial permanency should generally be avoided, in particular where a natural flow regime is a feasible management goal (Acreman et al. 2014). The changes in biodiversity and ecosystem function caused by the alteration of the temporal components of flow intermittency can change delivery of ecosystem services (Jorda-Capdevila \& RodríguezLabajos 2016). Although most studies have considered the influence of a minimum flow on human wellbeing, from the local climate moderation to the generation of a pleasant waterscape (Gopal 2016), recent work has also recognised the importance of dry river beds, for example as walking trails, migration corridors for shepherds, as a source of medicinal plants, and for capturing aestivating catfish (Steward et al. 2012). Finally, the 
cultural values of temporary waterways are increasingly acknowledged (Dee et al. 2017), and should also be integrated into flow management practices whenever relevant.

\section{ii) Methodological approaches to design eflows in temporary}

\section{waterways}

Due to the lack of approaches accounting for flow intermittency in eflows design, some river basin district authorities have prescribed a minimum flow in order to maintain at least connected pools that preserve refuges for biota during dry periods in overexploited rivers (e.g., Pla Sectorial de Cabals de Manteniment de les conques internes de Catalunya 2005). However, those preventive approaches are often not enough to restore and preserve essential ecosystem aspects in temporary waterways, and additional guidance is needed to incorporate current undestanding of flow intermittency into environmental flow assessment methods, also judged as suitable for application in temporary waterways. In this section we provide such guidance.

\section{Hydrological methods}

Hydrological methods for designing eflows constitute a first level of analysis and the only option when data and time are limited (Arthington 2012). Hydrological methods have been developed for broad-scale planning (Pastor et al. 2013), because they are based on indicators whose reliability is not sensitive to river length. Indeed, they can be applied to any point on a river for which flow data are available. Specifically, and due to the typical absence of data, natural flow regime time series can be derived by combining hydrological impacts with measured flow (i.e. by adding the water abstractions or subtracting point sources discharges to measured flow) or simulated using hydrological models (De Girolamo et al. 2017b). Widely applied methods include the Montana method (Tennant 1976), which recommends various levels of eflows based on specified proportions of the mean flow, and flow duration curve analysis (Matthews \& Bao 1991; Petts 2009), based on the probability that flow in a stream will equal or exceed a particular value. These methods propose a minimum level of streamflow to limit excessive water abstraction, which reduces and alters the aquatic habitat. However, they may not be appropriate for rivers where flow is highly unpredictable and sometimes 
ceases naturally, especially where habitat degradation comes from the artificial permanency.

The Range of Variability Approach (RVA) (Richter et al. 1996) provides a comprehensive statistical characterisation of ecologically relevant hydrological indicators that represent the duration, frequency, timing and predictability of flows, but also non-flow events, i.e. dry periods. Thus, the RVA assumes that the full range of variability of the flow regime is necessary to preserve river ecosystems (Poff et al. 1997), hence making it more suitable for the application in temporary waterways. Moreover, this method can be easily adapted by selecting those indicators that prove to be ecologically influential for temporary waterways (D’Ambrosio et al. 2017), and by excluding those with negligible effects.

Here we make a well-argued proposal of indicators, each of them suitable for enhancing a specific ecological function (Table 1), and we illustrate their use based on a study of the Celone River (Italian Peninsula). For many years, the environmental flow in the Celone has been fixed by the river basin district authority in a range defined by the $7 Q_{10}$ (lowest flow that occurs for seven consecutive days in a 10-year return period) and the $Q_{335}$ (quantile 335 of the flow-duration curve). However, this method does not guarantee that flow variability mimics the natural regime, which is one of the fundamental principles of eflows. The goal of using the RVA method and including our modifications is the incorporation of natural dry periods in the simulated environmental flow regimes. Thus, we use a predictability index, as the six-month seasonal predictability of the dry period, designed to protect species adapted to temporary conditions (Williams 2006; Wissinger, Greig \& McIntosch 2008; Gallart et al. 2012). Indices based on the number of flow and non-flow months and days provide information about the non-flow phase and the duration required to maintain the structure of river morphology, riparian cover, habitat, and communities (Arscott et al. 2010; Larned et al. 2010). The monthly flow and the annual minimum flow of 30 and 90 consecutive days are able to describe the transitions from a flowing river to connected pools, disconnected pools and dry river bed, which sustain the life cycle of native species (Poff et al. 1997; Richter et al. 1998; García-Roger et al. 2011). Finally, indicators of the magnitude, duration, frequency, timing and rate of change of high flows, already used in permanent rivers, are also included. All indicators are derived from historical daily flows and calculated annually for at least 20 years 
(considered as a representative time series). To calculate the timing of high flows, we define the previous and next month of the mode (i.e. the month with the highest number of yearly highest flows) as the limits of the suitable period of high flows. For other indicators, we fix the $25^{\text {th }}$ and $75^{\text {th }}$ percentiles as the minimum and maximum values of the range where the designed environmental flow regime should be established. Percentiles here are more suitable than using \pm 1 standard deviation from the mean because data may not be normally distributed and their covariance may be high.

Once all indicators are calculated, and as in the current RVA method, the procedure is monitored and revised based on biological data, such as those describing bioindicators used to assess ecological status in the Water Framework Directive (i.e. macroinvertebrates, fish, diatoms and macrophytes) (Belmar et al. 2018). This is done in a process of successive approximations able to identify relationships between biota and flow regime. At this stage, reference values need to be carefully defined in temporary waterways according to the hydrological regimes. Then, the environmental flow designers select a range of ecologically acceptable variability of each indicator, such as is done in the Ecological Limits of Hydrological Alteration (ELOHA) framework (Poff et al. 2010).

The particular assessment in the Celone River was performed downstream of a reservoir, and each indicator was calculated by using simulated streamflow data obtained from a hydrological model, and measured streamflow under current conditions in the impacted reach (De Girolamo et al. 2017b; a). Results from our adapted methodology show that a new environmental flow regime for the Celone River should include a non-flow period from June to October and 2-5 high flow pulses between February and April (Fig. 1).

\section{Hydraulic-habitat models}

Hydraulic-habitat models complement hydrological methods by incorporating flowdependent ecological data, such as the occurrence of wetted areas and the connectivity between them, the local hydraulic-habitat conditions of water depth and flow velocity, the presence of ecological refuges. The premise underlying hydraulic-habitat models is that biotic communities in rivers are limited by hydraulic-habitat availability. Thus, these models simulate spatial and temporal variability in physical habitat characteristics, such as depth, velocity, and substrate composition, which in turn are used to predict taxonomic 
occurrence and abundance (Ahmadi-Nedushan et al. 2006; Heggenes \& Wollebaek 2013). The most commonly used hydraulic-habitat models, such as PHABSIM (Bovee 1982) and CASiMiR (Jorde et al. 2001), work at the microhabitat scale, referring to a single point (or river element) that is evaluated to determine its suitability as hydraulic habitat.

Although hydraulic models have been used for characterising habitats during flowing phases and for managing low flows by maintaining isolated pools in temporary waterways (Theodoropoulos et al. 2019), they are unreliable for flow rates near zero and evidently do not describe non-flow periods. Coupled groundwater-surface water physical models are more appropriate but are still uncertain when flow is near zero (Seaman et al. 2016a). During non-flow periods, habitat characteristics other than local hydraulics are more important for biota, such as the connectivity and distance among wetted areas, river planforms and morphology, and water temperature and quality in disconnected pools (Gordon et al. 2004). Therefore, dynamics of these habitats are particularly important to describe. When flow decreases to zero, the aquatic habitat is reduced not instantly but gradually. This implies that, despite the non-flow conditions, water can remain stagnant in pools for a few days or for a longer period of time. The wetted area of the river, as well as the habitat availability in non-flow conditions, is then reduced according to the time since flow ceased at a rate that depends on the geomorphology of the river stretch, the groundwater level, the soil humidity and the weather conditions.

Mesohabitat methods, based on field surveys of habitat configurations on various occasions, are particularly effective for describing complex habitat dynamics during nonflow periods (Parasiewicz et al. 2013; Belletti et al. 2017). A first attempt to explore how habitat changes when water flows cease was carried out in the Gaià River (Iberian Peninsula) during both flow and non-flow phases (Fig. 2a). This provided detailed data on morphological (planforms, surface and connectivity of wetted areas), hydrological (streamflow time series, water depth and flow velocity patterns), vegetation (distribution and type), cover (refuges availability for biota) and sediment (size, patches, embeddedness) properties of the river (Belletti et al. 2017). After segmenting the river into homogeneous hydromorphological reaches, multiple, stage-dependent surveys of geomorphological units provided basic maps for the characterisation of mesohabitats 
(Fig. 2b), which were used to calculate spatio-temporal variation in habitat availability. These data were used to draw curves that represent the relationship between discharge and zero-flow days and wet area (Fig. 3a), habitat suitability for key species (Fig. 3b), and connectivity (Fig. 3c). The level of each variable can also be represented as a percentage of its maximum level.

As an example, a native fish species (European eel) was used as an ecological target, although macroinvertebrates could be also targeted (Parasiewicz et al. 2013; Vezza, Ghia \& Fea 2015). Rating curves were developed between flow and habitat, allowing to estimate habitat availability for fish species in space (\% of channel area) during both flow and non-flow phases. Lastly, habitat time series (Milhous et al. 1990) represented how physical habitat changes through time to identify deviation in habitat availability between reference and altered conditions. Increasing duration and frequency of flow events below minimum habitat thresholds may create catastrophically low habitat quantity for aquatic organisms. Several examples have been reported on frequency analysis of habitat (under-threshold) events, investigating current and future stress conditions that are created by persistent limitations in habitat availability (Parasiewicz et al. 2013; Vezza et al. 2015).

Environmental flows design should avoid these habitat bottlenecks and meso-scale habitat models can be used to simulate possible future scenarios and select the most appropriate one. This approach represents a feasible solution for different river morphological types (Belletti et al. 2017) and has been proven robust and quite universal (Parasiewicz et al. 2013). The combination of habitat-flow rating curve, habitat-time rating curve and habitat time series is an extension of meso-scale habitat models for application in temporary waterways, and can simulate habitat availability in current and future river flow and morphological conditions. Results from hydraulic-habitat models may then be used to calibrate hydrological methods by providing ecologically meaningful data.

\section{Holistic methods}

Holistic approaches use stepwise structured frameworks that collect, analyse and integrate data and knowledge to recommend flow levels to meet specific objectives (Acreman \& Dunbar 2004). By design, they include stakeholder engagement and 
adjustment of results through negotiation and consensus building, and thus require considerable time to overcome difficulties in their implementation. Widely applied basinscale approaches like the Downstream Response to Imposed Flow Transformation (DRIFT) (King, Brown \& Sabet 2003; King et al. 2014) and ELOHA (Poff et al. 2010) produce results showing the response of river systems to varying degrees of flow regime alteration, through plausible resource development scenarios. By including stepwise guidance on data and knowledge needs, they generally do not prescribe specific analytical methods to fill each data requirement. This makes holistic approaches flexible enough to be applied across a wide range of socio-ecological and biophysical conditions. Holistic approaches may thus incorporate the modified hydrological and hydraulic-habitat methods described above, or expert knowledge in the absence of empirical data.

To date, at least two published studies have applied holistic approaches in temporary waterways (Godinho et al. 2014; Seaman et al. 2016b). The first is a generic framework applied in the Säo Pedro, Brenhas and Amoreiras Rivers (Iberian Peninsula) (Godinho et al. 2014). It lays out a series of steps that enable the integration of hydrological, hydraulic rating, habitat simulation, and other methods in the formulation of environmental flow regimes to meet the biotic, hydromorphological and water quality criteria of the European Water Framework Directive. The second was applied to the Mokolo River (Southern Africa), which flows for $72-87 \%$ of the year (Seaman et al. 2016b). The DRIFT-ARID approach recognises the need to represent periods of unmeasurable surface flow when groundwater dynamics become controlling. An integrated groundwater-surface water model simulates daily groundwater depth, groundwater flow beneath the river, and net groundwater baseflow to the river (Prucha et al. 2016). Onset dates of non-flow and flowing periods are also new indicators that quantify the duration of unmeasurable surface flows.

As these examples demonstrate, existing holistic approaches may be applied to temporary waterways without significant structural alteration to their stepwise frameworks, but new component methods are needed to address flow-related aspects across both flow and non-flow periods of the flow regime. Key lessons learned from these experiences include the need for (i) improved knowledge of flow-ecology relationships in temporary waterways; (ii) delineation of different types of temporary waterways; (iii) 
increased terrestrial (e.g. soil science) and socio-economic knowledge in assessment teams to properly consider processes and interactions distinct from those in perennial rivers (Arce et al. 2019); (iv) incorporation of examples of desiccation-resistant biota such as aestivating fish (Polacik \& Podrabsky 2015), seed and egg banks (Brock et al. 2003; Rogers 2014) and terrestrial species that use the river bed during non-flow conditions (Steward et al. 2011); and (v) special emphasis on those non-flow ecological processes providing services with socioeconomic value to human communities. Regarding the first point, knowledge has grown considerably in recent years (Datry, Bonada \& Boulton 2017 ), thus facilitating the implementation of holistic approaches in temporary waterways whenever planned.

Holistic approaches also emphasise the socioeconomic aspects of resource protection for environmental flow assessment. Developed to incorporate socioeconomic knowledge into environmental management, the ecosystem services concept may account for the value that a designed environmental flow regime provides to human wellbeing (JordaCapdevila \& Rodríguez-Labajos 2016). The unpredictable character of temporary waterways and the distinction among phases provide additional values not accounted for in permanent rivers (Steward et al. 2012), such as the use of the dry river bed for cultural activities or the corridor for mammals appreciated by hunters (Sánchez-Montoya et al. 2016), but also interrupts the service provision - temporally and spatially - and complicates its evaluation (Koundouri et al. 2017).

The ecosystem services concept may improve inter-stakeholder dialogue, as synergies and tradeoffs are easily identified (Pahl-Wostl et al. 2013; Jorda-Capdevila \& RodríguezLabajos 2015). Considering ecosystem services is especially recommended when flow regimes need to be designed for modified and managed rivers (Acreman et al. 2014). Thus, new frameworks that incorporate service provision within environmental flow assessment should not only account for their values but also for power asymmetries to foster environmental justice (Gopal 2016; Jorda-Capdevila \& Rodríguez-Labajos 2017). The Sustainable Management of Hydrological Alteration (SUMHA) framework (PahlWostl et al. 2013), built on ELOHA, incorporates desirable ecosystem service goals that require negotiation in participatory settings. However, example applications of holistic methods that incorporate ecosystem services valuation are still missing. Finally, although 
not yet widely classified as water bodies protected by water policies, calls for greater attention to temporary waterways (Nikolaidis et al. 2013; Acuña et al. 2014; Marshall et al. 2018) encourage holistic approaches to incorporate policy considerations in the design and implementation of eflows. 


\section{Conclusions}

First, the main obstacle in the assessment and implementation of eflows in temporary waterways is the lack of hydrological data as well as of knowledge on the ecological effects of hydrological variability. Moreover, the study of flow intermittency by social and economic disciplines remains in its infancy.

Second, as revealed by actual applications, the habitat description of temporary waterways needs to combine specific hydrological variables (e.g. duration and timing of flow intermittency) and specific geomorphic/hydrogeologic/hydraulic elements (e.g. pool persistence and connectivity dynamics). In fact, the hydrology of temporary waterways should be precisely characterised to recognise their spatial and temporal variability. Hydrological methods can easily adapt to such variability and be implemented in any reservoir throughout a basin. However, hydrological data are typically unavailable, so models can rarely by applied to simulate both non-regulated and regulated conditions. This difficulty reinforces other approaches based on scenario comparisons, which focus on social and ecological objectives beyond natural conditions, and hence need to encompass elements other than hydrology.

Third, geomorphic and hydraulic elements (e.g. pool persistence and connectivity dynamics) describe the habitats that environmental flow designers aim to protect. Thus, hydraulic-habitat models relate geomorphic and hydraulic features in specific reaches to the flow regime and pursue flow objectives that target specific aquatic species, including those that have a terrestrial stage. However, for temporary waterways, such elements depend not only on the flow regime, but also on the time after the stream dries out, a variable that we identified as vital to incorporate for any eflows assessment. The analysis can be easily extended to life stages of various species that can be used as Indicators within hydraulic-habitat models developed for temporary waterways. Additionally, knowledge of groundwater levels and their influence on the maintenance of locally connected or disconnected pools in surface waters becomes key to correctly manage suitable eflows in temporary waterways.

Fourth, management objectives for the implementation of eflows should also include socio-economic perspectives (e.g., an ecosystem services-based approach). This means 
that managers should engage local stakeholders and balance a range of perspectives to adequately address eflows in temporary waterways. In this sense, holistic approaches are appropriate, since they include multiple type of variables and recall expert knowledge in situations with high uncertainty. 


\section{Authors' contributions}

All authors approved the final version to be published, and all questions related to the accuracy or integrity of any part of the authors' work have been appropriately investigated and resolved.

Note that we followed the CrediT system (https://casrai.org/credit/) and key references on the topic (Hunt 1991; Frassl et al. 2018). The CrediT has been used as system to evaluate individual contributions to the paper (see details in Table S1), which identified those meeting authorship criteria, as well as the order of the listed authors.

In sum, V Acuña conceived the ideas, coordinated the co-authors and led the Socioecological effects of flow intermittency section; D Jorda-Capdevila also coordinated the co-authors, and led the submission process and the design of figures; $P$ Vezza led the Hydraulic-habitat models section; AM De Girolamo led the Hydrological methods section; ME McClain led the Holistic methods section and made the English proofreading; $\mathrm{R}$ Stubbington also proofread the article and made multiple small contributions throughout the article, as well as AV Pastor, N Lamouroux, D von Schiller and A Munné. T Datry did an exhaustive revision of the article, pushed the work forward and organised the meeting in which this work started. 


\section{Acknowledgements}

This paper is based upon work from COST Action CA15113 (SMIRES, Science and Management of Intermittent Rivers and Ephemeral Streams; www.smires.eu) supported by COST (European Cooperation in Science and Technology). V Acuña and D JordaCapdevila also acknowledge the support from the Economy and Knowledge Department of the Catalan Government through Consolidated Research Group (ICRA-ENV 2017 SGR 1124) and from the CERCA. The Juan de la Cierva contract of $D$ Jorda-Capdevila (FJCl-2017-34977) is funded by La Agencia Estatal de Investigación del Ministerio de Ciencia Innovación y Universidades. The participation of D von Schiller was additionally supported by a Grant for Research Groups of the Basque University System (IT-951-16), funded by the Basque Government. Field work in the Gaià case study was supported by Mònica Bardina, Evelyn Garcia, and Carolina Solà. 


\section{Data availability statement}

Data about the Celone River case study are available via Mendeley Data http://dx.doi.org/10.17632/ytsy2yck5g.1 (De Girolamo, 2020).

Data about the Gaià River case study are available via Mendeley Data http://dx.doi.org/10.17632/7svhmvpxrs.1 (Vezza, 2020). 


\section{References}

Acreman, M., Arthington, A.H., Colloff, M.J., Couch, C., Crossman, N.D., Dyer, F., Overton, I., Pollino, C.A., Stewardson, M.J. \& Young, W. (2014) Environmental flows for natural, hybrid, and novel riverine ecosystems in a changing world. Frontiers in Ecology and the Environment, 12, 466-473.

Acreman, M.C. \& Dunbar, M.J. (2004) Defining environmental river flow requirements - a review. Hydrology and Earth System Sciences, 8, 861-876.

Acreman, M.C. \& Ferguson, A.J.D. (2010) Environmental flows and the European Water Framework Directive. Freshwater Biology, 55, 32-48.

Acuña, V., Datry, T., Marshall, J., Barceló, D., Dahm, C.N., Ginebreda, A., Mcgregor, G., Sabater, S., Tockner, K. \& Palmer, M.A. (2014) Why should we care about temporary waterways? Science, 343, 1080-1081.

Acuña, V., Giorgi, A., Muñoz, I., Uehlinger, U. \& Sabater, S. (2004) Flow extremes and benthic organic matter shape the metabolism of a headwater Mediterranean stream. Freshwater Biology, 49, 960-971.

Acuña, V., Hunter, M. \& Ruhí, A. (2017) Managing temporary streams and rivers as unique rather than second-class ecosystems. Biological Conservation, 211, 12-19.

Ahmadi-Nedushan, B., St-Hilaire, A., Bérubé, M., Robichaud, É., Thiémonge, N. \& Bobée, B. (2006) A review of statistical methods for the evaluation of aquatic habitat suitability for instream flow assessment. River Research and Applications, 22, 503523.

Arce, M.I., Mendoza-Lera, C., Almagro, M., Catalán, N., Romaní, A.M., Martí, E., Gómez, R., Bernal, S., Foulquier, A., Mutz, M., Marcé, R., Zoppini, A., Gionchetta, G., Weigelhofer, G., del Campo, R., Robinson, C.T., Gilmer, A., Rulik, M., Obrador, B., Shumilova, O., Zlatanović, S., Arnon, S., Baldrian, P., Singer, G., Datry, T., Skoulikidis, N., Tietjen, B. \& von Schiller, D. (2019) A conceptual framework for understanding the biogeochemistry of dry riverbeds through the lens of soil science. Earth-Science Reviews, 188, 441-453. 
Armstrong, A., Stedman, R.C., Bishop, J.A. \& Sullivan, P.J. (2012) What's a stream without water? Disproportionality in headwater regions impacting water quality. Environmental Management, 50, 849-860.

Arscott, D.B., Larned, S.T., Scarsbrook, M.R. \& Lambert, P. (2010) Aquatic invertebrate community structure along an intermittence gradient: Selwyn River, New Zealand. Journal of the North American Benthological Society, 29, 530-545.

Arthington, A. (2012) Environmental Flows. Saving Rivers in the Third Millenium. University of California Press, Berkeley, California.

Arthington, A.H., Bhaduri, A., Bunn, S.E., Jackson, S.E., Tharme, R.E., Tickner, D., Young, B., Acreman, M., Baker, N., Capon, S., Horne, A.C., Kendy, E., McClain, M.E., Poff, N.L., Richter, B.D. \& Ward, S. (2018) The Brisbane Declaration and Global Action Agenda on Environmental Flows (2018). Frontiers in Environmental Science, 6, 1-15.

Arthington, A.H., Bunn, S.E., Poff, L.N. \& Naiman, R.J. (2006) The challenge of providing environmental flow rules to sustian river ecosystems. Ecological Applications, 16, 1311-1318.

Arthington, A.H., Naiman, R.J., McClain, M.E. \& Nilsson, C. (2010) Preserving the biodiversity and ecological services of rivers: New challenges and research opportunities. Freshwater Biology, 55, 1-16.

Baker, D.B., Richards, R.P., Loftus, T.T. \& Kramer, J.W. (2004) A new flashiness index: characteristics and applications to midwestern rivers and streams. Journal of the American Water Resources Association, 40, 503-522.

Belletti, B., Rinaldi, M., Bussettini, M., Comiti, F., Gurnell, A.M., Mao, L., Nardi, L. \& Vezza, P. (2017) Characterising physical habitats and fluvial hydromorphology: A new system for the survey and classification of river geomorphic units. Geomorphology, 283, 143-157.

Belmar, O., Vila-Martínez, N., Ibáñez, C. \& Caiola, N. (2018) Linking fish-based biological indicators with hydrological dynamics in a Mediterranean river: Relevance for environmental flow regimes. Ecological Indicators, 95, 492-501. 
Bogan, M.T., Boersma, K.S. \& Lytle, D.A. (2015) Resistance and resilience of invertebrate communities to seasonal and supraseasonal drought in arid-land headwater streams. Freshwater Biology, 60, 2547-2558.

Bovee, K.D. (1982) A Guide to Stream Habitat Analysis Using the Instream Flow Incremental Methodology. U.S. Fish and Wildlife Service, Fort Collins, Colorado, U.S.A.

Brock, M.A., Nielsen, D.L., Shiel, R.J., Green, J.D. \& Langley, J.D. (2003) Drought and aquatic community resilience: The role of eggs and seeds in sediments of temporary wetlands. Freshwater Biology, 48, 1207-1218.

Bunn, S.E. \& Arthington, A.H. (2002) Basic principles and ecological consequences of altered flow regimes for aquatic biodiversity. Environmental Management, 30, 492507.

Colls, M., Timoner, X., Sabater, S. \& Acuňa, V. (2019) Effects of duration and frequency of the non-flow period on stream metabolism. Ecosystems.

D’Ambrosio, E., De Girolamo, A.M., Barca, E., lelpo, P. \& Rulli, M.C. (2017) Characterising the hydrological regime of an ungauged temporary river system: a case study. Environmental Science and Pollution Research, 24, 13950-13966.

Datry, T. (2012) Benthic and hyporheic invertebrate assemblages along a flow intermittence gradient: effects of duration of dry events. Freshwater Biology, 57, 563-574.

Datry, T., Bonada, N. \& Boulton, A. (eds). (2017) Intermittent Rivers and Ephemeral Streams, 1st ed. Academic Press, Cambridge, U.S.A.

Datry, T., Larned, S.T. \& Tockner, K. (2014) Intermittent Rivers: A Challenge for Freshwater Ecology. Bioscience, 64, 229-235.

Dee, L.E., Allesina, S., Bonn, A., Eklöf, A., Gaines, S.D., Hines, J., Jacob, U., McDonaldMadden, E., Possingham, H., Schröter, M. \& Thompson, R.M. (2017) Operationalizing Network Theory for Ecosystem Service Assessments. Trends in Ecology and Evolution, 32, 118-130. 
Döll, P. \& Schmied, H.M. (2012) How is the impact of climate change on river flow regimes related to the impact on mean annual runoff? A global-scale analysis. Environmental Research Letters, 7, 014037.

Döll, P. \& Zhang, J. (2010) Impact of climate change on freshwater ecosystems: a globalscale analysis of ecologically relevant river flow alterations. Hydrology and Earth System Sciences, 14, 783-799.

Eng, K., Wolock, D.M. \& Dettinger, M.D. (2016) Sensitivity of intermittent streams to climate variations in the USA. River Research and Applications, 32, 885-895.

European Commission. (2016) Ecological Flows in the Implementation of the Water Framework Directive: Guidance Document Nº31.

Frassl, M.A., Hamilton, D.P., Denfeld, B.A., de Eyto, E., Hampton, S.E., Keller, P.S., Sharma, S., Lewis, A.S.L., Weyhenmeyer, G.A., O'Reilly, C.M., Lofton, M.E. \& Catalán, N. (2018) Ten simple rules for collaboratively writing a multi-authored paper. PLOS Computational Biology, 14, e1006508.

Gallart, F. \& Llorens, P. (2004) Observations on land cover changes and water resources in the headwaters of the Ebro catchment, Iberian Peninsula. Physics and Chemistry of the Earth, 29, 769-773.

Gallart, F., Prat, N., García-Roger, E.M., Latron, J., Rieradevall, M., Llorens, P., Barberá, G.G., Brito, D., De Girolamo, A.M., Lo Porto, A., Buffagni, A., Erba, S., Neves, R., Nikolaidis, N.P., Perrin, J.L., Querner, E.P., Quiñonero, J.M., Tournoud, M.G., Tzoraki, O., Skoukulidis, N., Gomez, R., Sanchez-Montoya, M. \& Froebrich, J. (2012) A novel approach to analyzing the regimes of temporary streams in relation to their controls on the composition and structure of aquatic biota. Hydrology and Earth System Sciences, 16, 1-18.

García-Roger, E.M., del Mar Sánchez-Montoya, M., Gómez, R., Suárez, M.L., VidalAbarca, M.R., Latron, J., Rieradevall, M. \& Prat, N. (2011) Do seasonal changes in habitat features influence aquatic macroinvertebrate assemblages in perennial versus temporary Mediterranean streams? Aquatic Sciences, 73, 567-579. 
Garcia, C., Amengual, A., Homar, V. \& Zamora, A. (2017a) Losing water in temporary streams on a Mediterranean island: Effects of climate and land-cover changes. Global and Planetary Change, 148, 139-152.

Garcia, C., Gibbins, C.N., Pardo, I. \& Batalla, R.J. (2017b) Long term flow change threates invertebrate diversity in temporary streams: evidence from an island. Science of the Total Environment, 580, 1453-1549.

Gehrke, P.C. \& Harris, J.H. (2001) Regional-scale effects of flow regulation on lowland riverine fish communities in New South Wales, Australia. Regulated Rivers: Research \& Management, 17, 369-391.

Gerten, D., Hoff, H., Rockström, J., Jägermeyr, J., Kummu, M. \& Pastor, A. V. (2013) Towards a revised planetary boundary for consumptive freshwater use: Role of environmental flow requirements. Current Opinion in Environmental Sustainability, 5, 551-558.

De Girolamo, A.M. (2020) Data from: Natural streamflow and IHAs. Celone River case study. Mendeley Data, V1, http://dx.doi.org/10.17632/ytsy2yck5g.1

De Girolamo, A.M., Barca, E., Pappagallo, G. \& Lo Porto, A. (2017a) Simulating ecologically relevant hydrological indicators in a temporary river system. Agricultural Water Management, 180, 194-204.

De Girolamo, A.M., Bouraoui, F., Buffagni, A., Pappagallo, G. \& Lo Porto, A. (2017b) Hydrology under climate change in a temporary river system: Potential impact on water balance and flow regime. River Research and Applications, 33, 1219-1232.

Godinho, F., Costa, S., Pinheiro, P., Reis, F. \& Pinheiro, A. (2014) Integrated procedure for environmental flow assessment in rivers. Environmental Processes, 1, 137-147.

Gopal, B. (2016) A conceptual framework for environmental flows assessment based on ecosystem services and their economic valuation. Ecosystem Services, 21, 53-58.

Gordon, N., McMahon, T., Finlayson, B., Gippel, C. \& Nathan, R. (2004) Stream Hydrology: An Introduction for Ecologists. Wiley, Hoboken, U.S.A. 
Heggenes, J. \& Wollebaek, J. (2013) Habitat Use and Selection by Brown Trout in Streams. Ecohydraulics: an integrated approach (eds I. Maddock, A. Harby, P. Kemp, \& P.J. Wood), p. 462. John Wiley \& Sons, Ltd, Chichester, United Kingdom.

Hunt, R. (1991) Trying an authorship index. Nature, 352, 187.

Jacobson, P.J. \& Jacobson, K.M. (2013) Hydrologic controls of physical and ecological processes in Namib Desert ephemeral rivers: Implications for conservation and management. Journal of Arid Environments, 93, 80-93.

Jaeger, K.L., Olden, J.D. \& Pelland, N.A. (2014) Climate change poised to threaten hydrologic connectivity and endemic fishes in dryland streams. Proceedings of the National Academy of Sciences of the United States of America, 111, 13894-13899.

Jorda-Capdevila, D. \& Rodríguez-Labajos, B. (2015) An ecosystem service approach to understand conflicts on river flows: local views on the Ter River (Catalonia). Sustainability Science, 10, 463-477.

Jorda-Capdevila, D. \& Rodríguez-Labajos, B. (2016) Socioeconomic value(s) of restoring environmental flows: systematic review and guidance for assessment. River research and applications.

Jorda-Capdevila, D. \& Rodríguez-Labajos, B. (2017) Embracing complexity improves the assessment of environmental flows - One step beyond Gopal's (2016) framework. Ecosystem Services, 25, 79-81.

Jorde, K., Chneider, M., Peter, A. \& Zöllner, F. (2001) Models for the evaluation of fish habitat quality and instream flow assessment. International Symposium on Environmental Hydraulics, p. Tempe, U.S.A.

King, J., Beuster, H., Brown, C. \& Joubert, A. (2014) Pro-active management: the role of environmental flows in transboundary cooperative planning for the Okavango River system. Hydrological Sciences Journal, 59, 786-800.

King, J., Brown, C. \& Sabet, H. (2003) A scenario-based holistic approach to environmental flow assessments for rivers. River Research and Applications, 19, 619-639. 
King, J. \& Louw, D. (1998) Instream flow assessments for regulated rivers in South Africa using the Building Block Methodology. Aquatic Ecosystem Health and Management, 1, 109-124.

Konrad, C.P., Brasher, A.M.D. \& May, J.T. (2008) Assessing streamflow characteristics as limiting factors on benthic invertebrate assemblages in streams across the western United States. Freshwater Biology, 53, 1983-1998.

Koundouri, P., Boulton, A.J., Datry, T. \& Souliotis, I. (2017) Ecosystem Services, Values, and Societal Perceptions of Intermittent Rivers and Ephemeral Streams. Intermittent Rivers and Ephemeral Streams: Ecology and Management (eds T. Datry, N. Bonada, \& A.J. Boulton), pp. 455-476. Academic Press.

Kummu, M., Guillaume, J.H.A., de Moel, H., Eisner, S., Flörke, M., Porkka, M., Siebert, S., Veldkamp, T.I.E. \& Ward, P.J. (2016) The world's road to water scarcity: shortage and stress in the 20th century and pathways towards sustainability. Scientific Reports, 6, 38495.

Lamouroux, N. \& Jowett, I.G. (2005) Generalized instream habitat models. Canadian Journal of Fisheries and Aquatic Sciences, 62, 7-14.

Larned, S.T., Datry, T., Arscott, D.B. \& Tockner, K. (2010) Emerging concepts in temporary-river ecology. Freshwater Biology, 55, 717-738.

Leigh, C., Boersma, K.S., Galatowitsch, M.L., Milner, V.S. \& Stubbington, R. (2019) Are all rivers equal? The role of education in attitudes towards temporary and perennial rivers. People and Nature, 181-190.

Leigh, C. \& Datry, T. (2017) Drying as a primary hydrological determinant of biodiversity in river systems: a broad-scale analysis. Ecography, 40, 487-499.

Marshall, J.C., Acuña, V., Allen, D.C., Bonada, N., Boulton, A.J., Carlson, S.M., Dahm, C.N., Datry, T., Leigh, C., Negus, P., John, S.R., Sabater, S., Steward, A.L., Stubbington, R., Tockner, K. \& Vander Vorste, R. (2018) Protecting US river health by maintaining the legal status of their temporary waterways. Science, 361, 857.

Matthews, R.C. \& Bao, Y. (1991) The Texas method of preliminary Instream Flow Determination. Rivers, 2, 295-310. 
Milhous, R.T., Bartholow, J.M., Updike, M.A. \& Moss, A.R. (1990) Reference Manual for Generation and Analysis of Habitat Time Series: Version II. Fort Collins, Colorado, U.S.A.

Múrria, C., Bonada, N. \& Prat, N. (2008) Effects of the invasive species Potamopyrgus antipodarum (Hydrobiidae, Mollusca) on community structure in a small Mediterranean stream. Fundamental and Applied Limnology, 171, 131-143.

Nikolaidis, N.P., Demetropoulou, L., Froebrich, J., Jacobs, C., Gallart, F., Prat, N., Lo Porto, A., Campana, C., Papadoulakis, V., Skoulikidis, N., Davy, T., Bidoglio, G., Bouraoui, F., Kirkby, M., Tournound, M.-G., Polesello, S., Barberà, G.G., Cooper, D., Gómez, R., del Mar Sanchezx-Montoya, M., Latron, J., De Girolamo, A.M. \& Perrin, J.-L. (2013) Towards sustainable management of Mediterranean river basins: policy recommendations on management aspects of temporary streams. Water Policy, 15, 830-849.

Pahl-Wostl, C., Arthington, A., Bogardi, J., Bunn, S.E., Hoff, H., Lebel, L., Nikitina, E., Palmer, M., Schulze, R., Poff, L.N., Richards, K., Schlu, M., St-hilaire, A., Tharme, R., Tockner, K. \& Tsegai, D. (2013) Environmental flows and water governance: Managing sustainable water uses. Current Opinion in Environmental Sustainability, 5, 341-351.

Parasiewicz, P., Rogers, J.N., Vezza, P., Gortázar, J., Seager, T., Pegg, M., Wiśniewolski, W. \& Comoglio, C. (2013) Applications of the MesoHABSIM Simulation Model. Ecohydraulics: an integrated approach, pp. 109-124. John Wiley \& Sons, Ltd, Hoboken, U.S.A.

Pastor, A. V., Ludwig, F., Biemans, H., Hoff, H. \& Kabat, P. (2013) Accounting for environmental flow requirements in global water assessments. Hydrology and Earth System Sciences, 10, 14987-15032.

Pekel, J.-F., Cottam, A., Gorelick, N. \& Belward, A.S. (2016) High-resolution mapping of global surface water and its long-term changes. Nature, 540, 418-422.

Petts, G.E. (1984) Impounded Rivers: Perspectives for Ecological Management. John Wiley \& Sons Ltd., Chichester, United Kingdom. 
Petts, G.E. (2009) Instream flow science for sustainable river management. Journal of the American Water Resources Association, 45, 1071-1086.

Pla Sectorial de Cabals de Manteniment de Les Conques Internes de Catalunya. (2005) Barcelona, Spain.

Poff, N.L., Allan, J.D., Bain, M.B., Karr, J.R., Prestegaard, K.L., Richter, B.D., Sparks, R.E. \& Stromberg, J.C. (1997) The natural flow regime. BioScience, 47, 769-784.

Poff, N.L., Olden, J.D., Merritt, D.M. \& Pepin, D.M. (2007) Homogenization of regional river dynamics by dams and global biodiversity implications. Proceedings of the National Academy of Sciences, 104, 5732-5737.

Poff, N.L., Richter, B.D., Arthington, A.H., Bunn, S.E., Naiman, R.J., Kendy, E., Acreman, M., Apse, C., Bledsoe, B.P., Freeman, M.C., Henriksen, J., Jacobson, R.B., Kennen, J.G., Merritt, D.M., O'Keeffe, J.H., Olden, J.D., Rogers, K., Tharme, R.E. \& Warner, A. (2010) The ecological limits of hydrologic alteration (ELOHA): A new framework for developing regional environmental flow standards. Freshwater Biology, 55, 147170.

Poff, N.L. \& Ward, J. V. (1989) Implications of streamflow variability and predictability for lotic community structure: a regional analysis of streamflow patterns. Canadian Journal of Fisheries and Aquatic Sciences, 46, 1805-1818.

Poff, N.L. \& Zimmerman, J.K.H. (2010) Ecological responses to altered flow regimes: A literature review to inform the science and management of environmental flows. Freshwater Biology, 55, 194-205.

Polacik, M. \& Podrabsky, J.E. (2015) Temporary environments. Extremophile fishes (eds R. Riesch, M. Tobler, \& M. Plath), pp. 217-245. Springer International Publishing, Berlin, Germany.

Poznańska, M., Kakareko, T., Krzyżyński, M. \& Kobak, J. (2013) Effect of substratum drying on the survival and migrations of Ponto-Caspian and native gammarids (Crustacea: Amphipoda). Hydrobiologia, 700, 47-59.

Prucha, B., Graham, D., Watson, M., Avenant, M., Esterhuyse, S., Joubert, A., Kemp, M., King, J., Le Roux, P., Redelinghuys, N. \& Rossouw, L. (2016) MIKE-SHE integrated 
groundwater and surface water model used to simulate scenario hydrology for input to DRIFT-ARID: the Mokolo River case study. Water SA, 42, 384-398.

Pumo, D., Caracciolo, D., Viola, F. \& Noto, L. V. (2016) Climate change effects on the hydrological regime of small non-perennial river basins. Science of the Total Environment, 542, 76-92.

Richter, B.D., Baumgartner, J. V., Braun, D.P. \& Powell, J. (1998) A spatial assessment of hydrologic alteration within a river network. Regulated rivers: research \& management, 14, 329-340.

Richter, B.D., Baumgartner, J. V, Powell, J. \& Braun, D.P. (1996) A method for assessing hydrologic alteration within ecosystems. Conservation Biology, 10, 1163-1174.

Richter, B.D., Warner, A.T., Meyer, J.L. \& Lutz, K. (2006) A collaborative and adaptive process for developing environmental flow recommendations. River Research and Applications, 22, 297-318.

Rogers, D.C. (2014) Hatching response to temperature along a latitudinal gradient by the fairy shrimp Branchinecta lindahli (Crustacea; Branchiopoda; Anostraca) in culture conditions. Journal of Limnology, 74, 85-94.

Sánchez-Montoya, M.M., Moleón, M., Sánchez-Zapata, J.A. \& Tockner, K. (2016) Dry riverbeds: Corridors for terrestrial vertebrates. Ecosphere, 7, 1-10.

Schneider, A., Jost, A., Coulon, C., Silvestre, M., Théry, S. \& Ducharne, A. (2017) Globalscale river network extraction based on high-resolution topography and constrained by lithology, climate, slope, and observed drainage density. Geophysical Research Letters, 44, 2773-2781.

Schneider, C., Laizé, C.L.R., Acreman, M.C. \& Flörke, M. (2013) How will climate change modify river flow regimes in Europe? Hydrology and Earth System Sciences, 17, 325-339.

Seaman, M., Watson, M., Avenant, M., Joubert, A., King, J., Barker, C., Esterhuyse, S., Graham, D., Kemp, M., Le Roux, P., Prucha, B., Redelinghuys, N., Rossouw, L., Rowntree, K., Sokolic, F., Van Rensburg, L., Van Der Waal, B., Van Tol, J. \& Vos, T. (2016a) DRIFT-ARID: Application of a method for environmental water requirements 
(EWRs) in a non-perennial river (Mokolo River) in South Africa. Water SA, 42, 368383.

Seaman, M., Watson, M., Avenant, M., King, J., Joubert, A., Barker, C., Esterhuyse, S., Graham, D., Kemp, M., Le Roux, P. \& Prucha, B. (2016b) DRIFT-ARID: A method for assessing environmental water requirements (EWRs) for non-perennial rivers. Water SA, 42, 356-367.

Shumilova, O., Zak, D., Datry, T., von Schiller, D., Corti, R., Foulquier, A., Obrador, B., Tockner, K., Allan, D.C., Altermatt, F., Arce, M.I., Arnon, S., Banas, D., BanegasMedina, A., Beller, E., Blanchette, M.L., Blanco-Libreros, J.F., Blessing, J., Boëchat, I.G., Boersma, K., Bogan, M.T., Bonada, N., Bond, N.R., Brintrup, K., Bruder, A., Burrows, R., Cancellario, T., Carlson, S.M., Cauvy-Fraunié, S., Cid, N., Danger, M., de Freitas Terra, B., Girolamo, A.M. De, del Campo, R., Dyer, F., Elosegi, A., Faye, E., Febria, C., Figueroa, R., Four, B., Gessner, M.O., Gnohossou, P., Cerezo, R.G., Gomez-Gener, L., Graça, M.A.S., Guareschi, S., Gücker, B., Hwan, J.L., Kubheka, S., Langhans, S.D., Leigh, C., Little, C.J., Lorenz, S., Marshall, J., McIntosh, A., Mendoza-Lera, C., Meyer, E.I., Miliša, M., Mlambo, M.C., Moleón, M., Negus, P., Niyogi, D., Papatheodoulou, A., Pardo, I., Paril, P., Pešić, V., Rodriguez-Lozano, P., Rolls, R.J., Sanchez-Montoya, M.M., Savić, A., Steward, A., Stubbington, R., Taleb, A., Vorste, R. Vander, Waltham, N., Zoppini, A. \& Zarfl, C. (2019) Simulating rewetting events in intermittent rivers and ephemeral streams: A global analysis of leached nutrients and organic matter. Global Change Biology, 25, 1591-1611.

Stanalker, C., Lamb, B.L., Henriksen, J., Bovee, K. \& Bartholow, J. (1995) The Instream Flow Incremental Methodology. A Primer for IFIM. Biological Report, 29, 53.

Steward, A.L., Marshall, J.C., Sheldon, F., Harch, B., Choy, S., Bunn, S.E. \& Tockner, K. (2011) Terrestrial invertebrates of dry river beds are not simply subsets of riparian assemblages. Aquatic Sciences, 73, 551-566.

Steward, A.L., von Schiller, D., Tockner, K., Marshall, J.C. \& Bunn, S.E. (2012) When the river runs dry: human and ecological values of dry riverbeds. Frontiers in Ecology and the Environment, 10, 202-209. 
Tennant, D.L. (1976) Instream flow regimens for fish, wildlife, recreation and related environmental resources. Fisheries, 1, 6-10.

Theodoropoulos, C., Papadaki, C., Vardakas, L., Dimitriou, E., Kalogianni, E. \& Skoulikidis, N. (2019) Conceptualization and pilot application of a model-based environmental flow assessment adapted for intermittent rivers. Aquatic Sciences, 81, 10 .

Tonkin, J.D., Bogan, M.T., Bonada, N., Rios-Touma, B. \& Lytle, D.A. (2017) Seasonality and predictability shape temporal species diversity. Ecology, 98, 1201-1216.

Vezza, P. (2020) Data from: Meso-scale habitat description in the Gaià River (Tarragona, Spain). Mendeley Data, V1, http://dx.doi.org/10.17632/7svhmvpxrs.1

Vezza, P., Ghia, D. \& Fea, G. (2015) Quantitative habitat models for the conservation of the endangered European crayfish Austropotamobius pallipes complex. A Global Overview of the Conservation of Freshwater Decapod Crustaceans (eds T. Kawai \& N. Cumberlidge), pp. 339-358. Springer International Publishing, Berlin, Germany.

Vezza, P., Muñoz-Mas, R., Martinez-Capel, F. \& Mouton, A. (2015) Random forests to evaluate biotic interactions in fish distribution models. Environmental Modelling and Software, 67, 173-183.

Williams, D.D. (2006) The Biology of Temporary Waters. Oxford University Press, Oxford, U.K.

Wissinger, S.A., Greig, H.S. \& Mclntosch, A. (2008) Absence of species replacements between permanent and temporary lentic communities in New Zealand. Journal of the North American Benthological Society, 28, 12-23.

Wohl, E., Bledsoe, B.P., Jacobson, R.B., Poff, N.L., Rathburn, S.L., Walters, D.M. \& Wilcox, A.C. (2015) The natural sediment regime in rivers: Broadening the foundation for ecosystem management. BioScience, 65, 358-371. 
Table 1. Adaptation of the Range of Variability Approach (RVA) for temporary waterways:

a selection of hydrological indicators that represent specific ecological functions.

\begin{tabular}{|c|c|c|c|}
\hline $\begin{array}{l}\text { Flow } \\
\text { components }\end{array}$ & $\begin{array}{l}\text { Hydrological } \\
\text { indicators }\end{array}$ & Example ecological functions & References \\
\hline $\begin{array}{l}\text { Flow } \\
\text { permanence }\end{array}$ & $\begin{array}{l}\text { Relative number of } \\
\text { months with flow }\end{array}$ & $\begin{array}{l}\text { Maintains structure of communities, } \\
\text { habitat, river morphology, riparian } \\
\text { cover. }\end{array}$ & $\begin{array}{l}\text { (Arscott et al. 2010; } \\
\text { Larned et al. 2010) }\end{array}$ \\
\hline Predictability & $\begin{array}{l}\text { Six-month } \\
\text { seasonal } \\
\text { predictability of } \\
\text { non-flow period }\end{array}$ & $\begin{array}{l}\text { Protects the development of } \\
\text { specialist species. }\end{array}$ & $\begin{array}{l}\text { (Williams 2006; } \\
\text { Wissinger, Greig \& } \\
\text { Mclntosch 2008; } \\
\text { Gallart et al. 2012) }\end{array}$ \\
\hline $\begin{array}{l}\text { Magnitude of } \\
\text { annual extreme } \\
\text { flow condition }\end{array}$ & $\begin{array}{l}\text { Annual 1-day } \\
\text { mean maximum }\end{array}$ & $\begin{array}{l}\text { Creates sites for colonisation and } \\
\text { supports abundance of invertebrate } \\
\text { assemblages. }\end{array}$ & $\begin{array}{l}\text { (Richter et al. 1998; } \\
\text { Poff \& Zimmerman } \\
\text { 2010) }\end{array}$ \\
\hline & $\begin{array}{l}\text { Annual 3-day } \\
\text { mean maximum } \\
\text { Annual 7-day } \\
\text { mean maximum }\end{array}$ & $\begin{array}{l}\text { Structures river channel morphology } \\
\text { and physical habitat condition. } \\
\text { Desiccates sensitive aquatic } \\
\text { species. }\end{array}$ & (Richter et al. 1998) \\
\hline & $\begin{array}{l}\text { Annual 30-day } \\
\text { mean minimum }\end{array}$ & $\begin{array}{l}\text { Sustains the life cycle of native } \\
\text { species, by causing anaerobic stress } \\
\text { in plants, and invertebrate } \\
\text { assemblage richness, by ensuring } \\
\text { transition from connected to } \\
\text { disconnected pools. }\end{array}$ & $\begin{array}{l}\text { (Richter et al. 1998; } \\
\text { Bunn \& Arthington } \\
\text { 2002; Poff et al. } \\
\text { 2010) }\end{array}$ \\
\hline & $\begin{array}{l}\text { Annual 90-day } \\
\text { mean minimum }\end{array}$ & $\begin{array}{l}\text { Controls the duration of stressful } \\
\text { conditions such as low oxygen and } \\
\text { high chemical concentrations; } \\
\text { promotes transition from riffle to } \\
\text { connected pools, which enhances } \\
\text { the abundance of aquatic fauna. }\end{array}$ & $\begin{array}{l}\text { (Poff et al. 1997; } \\
\text { Richter et al. 1998; } \\
\text { García-Roger et al. } \\
\text { 2011) }\end{array}$ \\
\hline $\begin{array}{l}\text { Magnitude of } \\
\text { flow on monthly } \\
\text { basis }\end{array}$ & $\begin{array}{l}\text { Average monthly } \\
\text { flow }\end{array}$ & $\begin{array}{l}\text { Maintains species diversity and } \\
\text { abundance and prevents } \\
\text { establishment of non-native species. }\end{array}$ & $\begin{array}{l}\text { (Konrad, Brasher \& } \\
\text { May 2008) }\end{array}$ \\
\hline $\begin{array}{l}\text { Duration and } \\
\text { timing of } \\
\text { extreme } \\
\text { condition }\end{array}$ & $\begin{array}{l}\text { Non-flow days } \\
\text { duration, Julian } \\
\text { date of maximum, } \\
\text { high pulse duration }\end{array}$ & $\begin{array}{l}\text { Prevents non-native species, which } \\
\text { are less tolerant to the absence of } \\
\text { flow, from becoming dominant. }\end{array}$ & (Poff \& Ward 1989) \\
\hline
\end{tabular}

This article is protected by copyright. All rights reserved 
Frequency

Rate of change
High pulse count

Flashiness index
Regulates community structure and promotes population persistency.

Prevents non-native species, less tolerant to flash floods than tolerant, and traps organisms in islands.
(Richter et al. 1998)

(Petts 1984; Richter et al. 1998; Baker et al. 2004; Konrad, Brasher \& May 2008)

This article is protected by copyright. All rights reserved 


\section{Figures}

Flow permanence

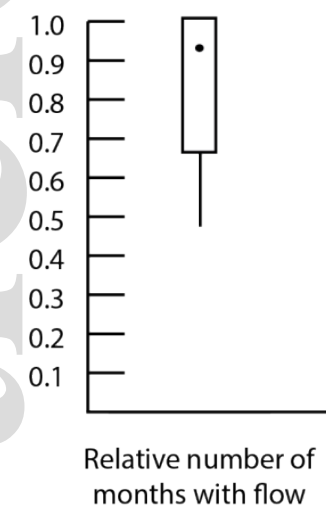

Frequency

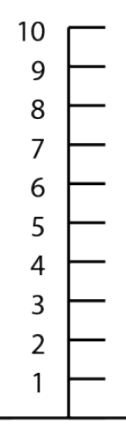

Rate of change

$$
\text { (2) }
$$

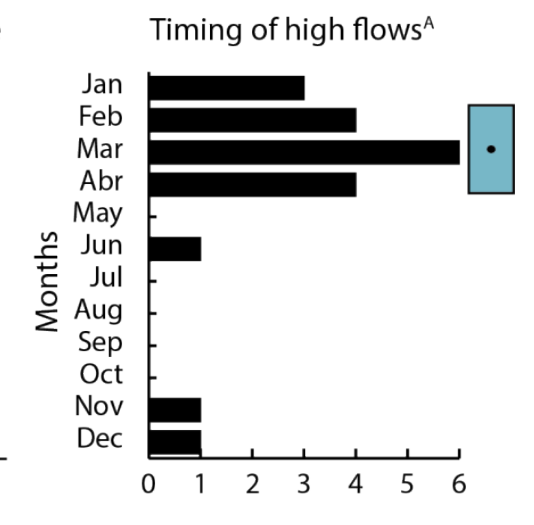

Number of yearly highest flows
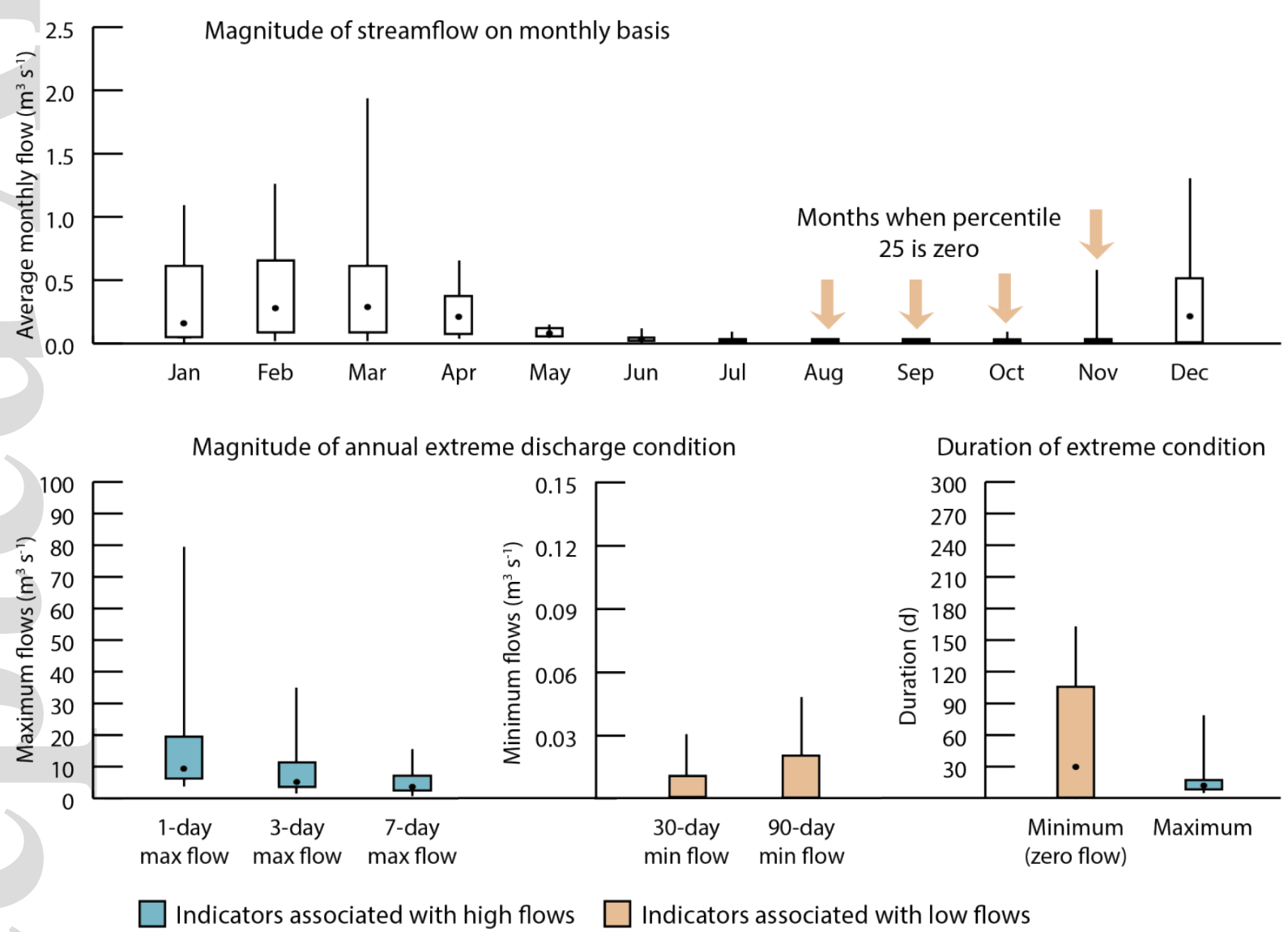

Figure 1. Indicator selection for the adaptation of the Range of Variability Approach (RVA) method to temporary waterways applied in the Celone River (Italian Peninsula). Lines show $5^{\text {th }}$ and $95^{\text {th }}$ percentiles, boxes $25^{\text {th }}$ and $75^{\text {th }}$ percentiles, and dots the median values higher than zero. For the timing of high flows, the dot corresponds to the mode and the box includes the previous and next months and shows the period in which high flows should be released. 
(a) Scheme of the sampled reach of the Gaià River

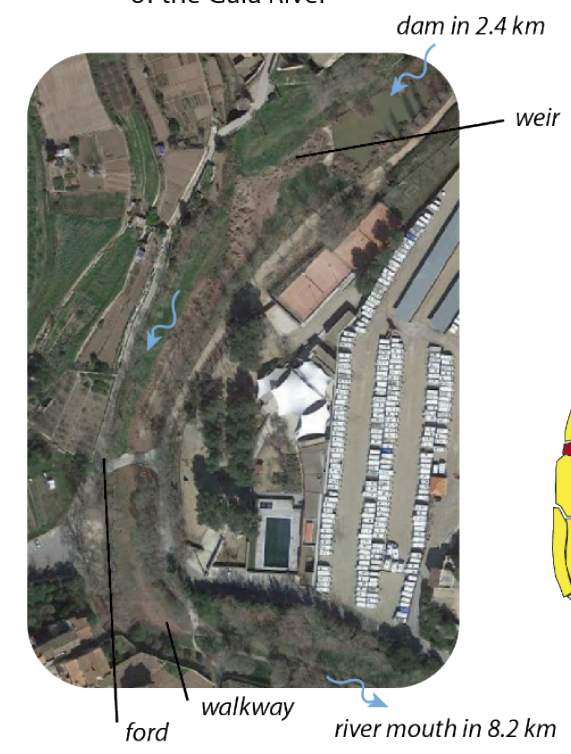

(b) Wet area and habitat suitability for juvenile Anguilla anguilla in different flow discharges and zero-flow days
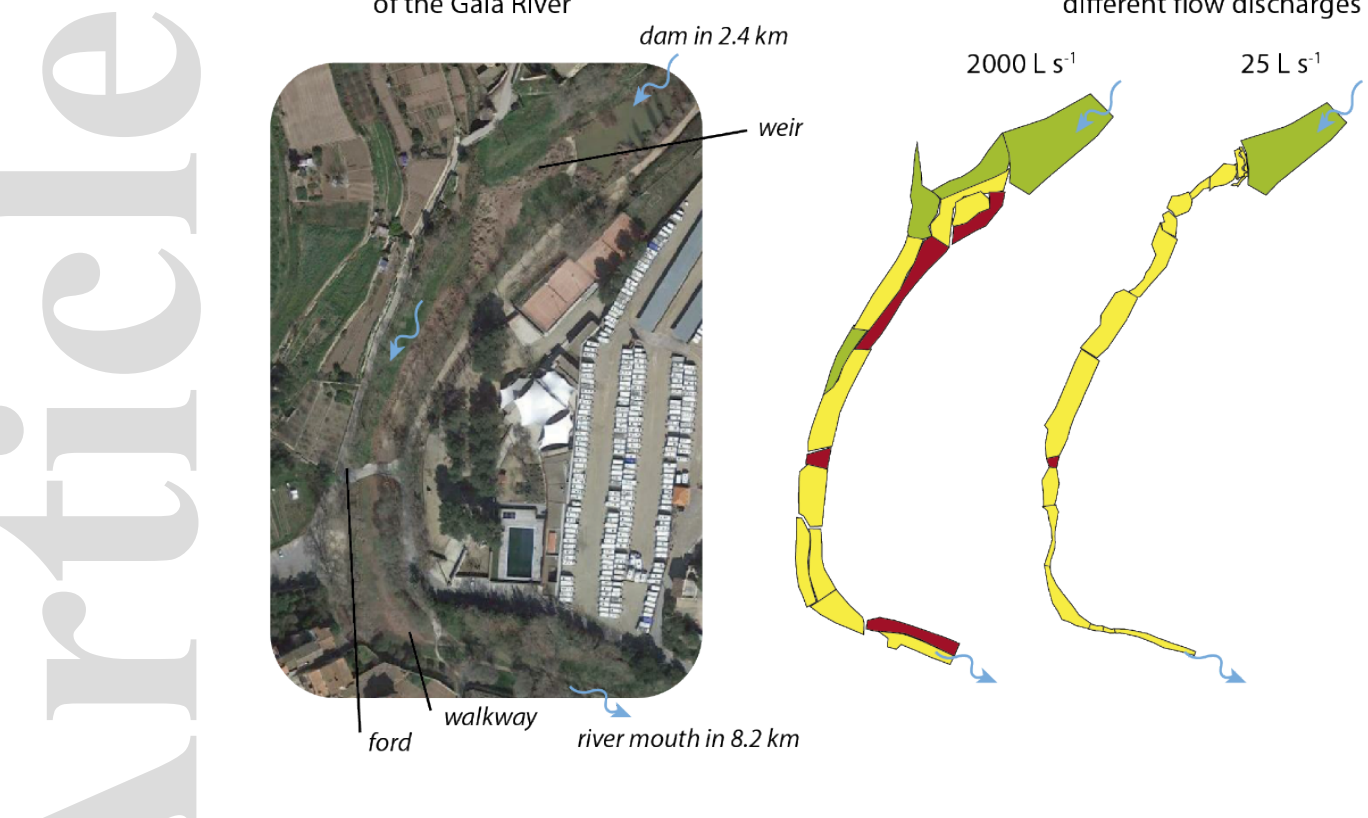

Figure 2. Application of the meso-scale hydraulic-habitat model (MesoHABSIM) to the Gaià River (Iberian Peninsula). We show here basic information for the studied reach (a) and the wet area and habitat suitability for the key specie European eel (Anguilla anguilla) in its juvenile life stage under different levels of flow discharge and non-flow days (b). 
(a) Wet area $\left(\mathrm{m}^{2}\right)$

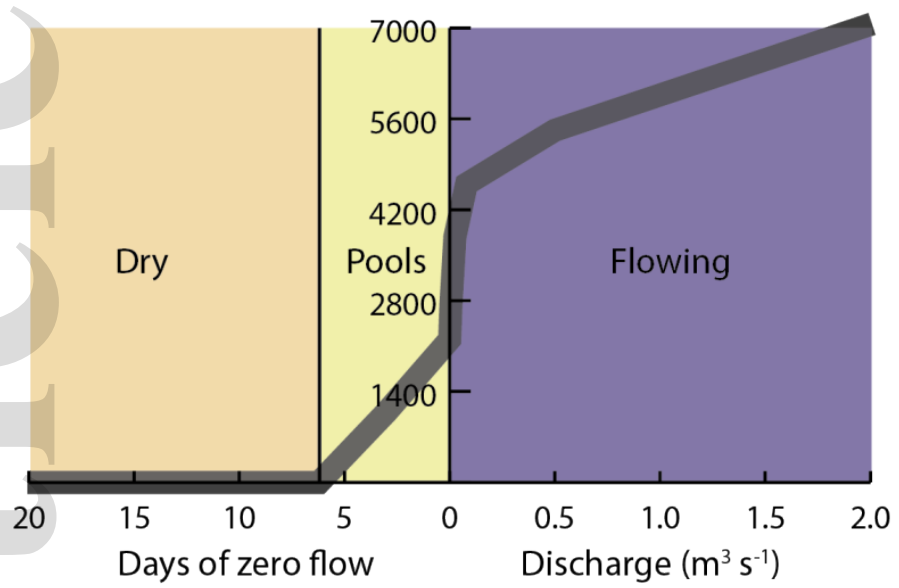

(b) Weighted Usable Area for Anguilla anguilla $\left(\mathrm{m}^{2}\right)$

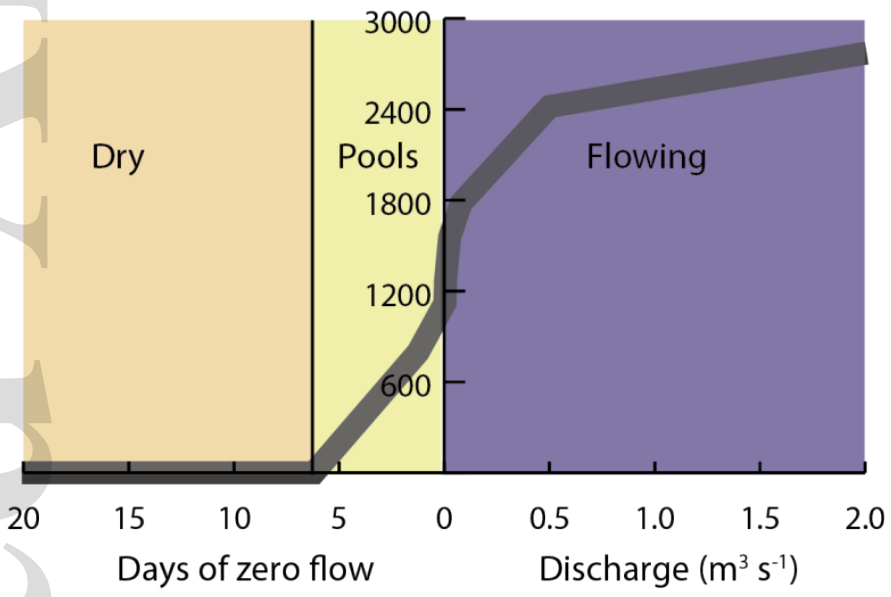

(c) Connectivity (m)

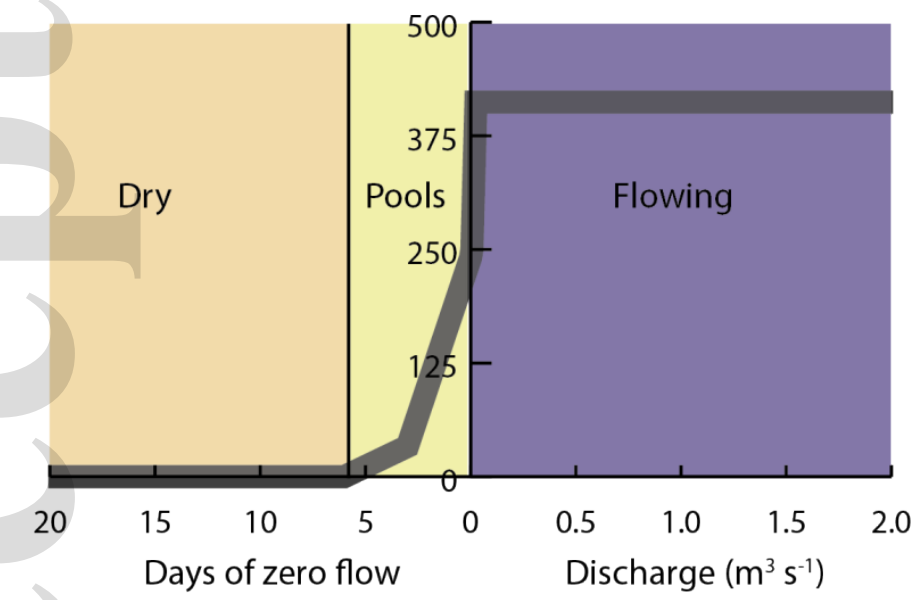

Figure 3. Adaptation of the hydraulic-mesohabitat models to temporary waterways by including the zero-flow-days axis in the graphs relating wet area (a), weighted usable area for key species (b) and connectivity (c) to flow discharge. Results shown are from the Gaià River (Iberian Peninsula), where the selected key species is European eel (Anguilla anguilla). 